\title{
A site-specific bifunctional protein labeling system for affinity and fluorescent analysis
}

Thomas S. Shute ${ }^{\dagger}$ Masayuki Matsushita, ${ }^{\S}$ Tobin J. Dickerson, ${ }^{\S}$ James J. La Clair, ${ }^{\dagger}$ Kim D.

$$
\text { Janda, }{ }^{*}, \S \text { Michael D. Burkart* }{ }^{, \dagger}
$$

$\dagger$ Department of Chemistry and Biochemistry, University of California, San Diego, 9500 Gilman Drive, La Jolla, CA 92093-0358 USA and the §Department of Chemistry, The Scripps Research Institute, 10550 North Torrey Pines Road, La Jolla, CA 92038 USA

Email to: mburkart@ucsd.edu orkdjanda@scripps.edu

\section{Experimental Section}

1. Synthesis of Stilbene-linked CoA

2. Production of stilbene-crypto-VibB

3. Fluorescent analysis of stilbene-bound protein with anti-stilbene antibody

4. Purification of crypto-VibB from crude lysate

5. Western blot analysis

6. Droplet analysis 


\section{Synthesis of Stilbene-linked CoA}

EP2-PEG1500- $\mathrm{NH}_{2}$ (4). Compound 2 (100 mg, $0.323 \mathrm{mmol}$ ) [see: A. Simeonov, M. Matsushita, E. A. Juban, E. H. Thompson, T. Z. Hoffman, A. E. Beuscher, M. J. Taylor, P. Wirsching, W. Rettig, J. K. McCusker, R. C. Stevens, D.P. Millar, P. G. Schultz, R. A. Lerner, K. D. Janda, Science. 2000, 290, 307-313] was added to a solution of $O, O^{\prime}$-bis (3-aminopropyl)polyethylene glycol $1500(3)(1.5 \mathrm{~g}, 1.0 \mathrm{mmol})$ that was dried by coevaporated twice with $\mathrm{CH}_{2} \mathrm{Cl}_{2}$-toluene $(20 \mathrm{~mL})$ and dissolved in $\mathrm{CH}_{2} \mathrm{Cl}_{2}(20 \mathrm{~mL})$. DIPEA (121 $\mu \mathrm{L}, 0.323 \mathrm{mmol}$ ), $N$-hydroxysuccinimide (NHS, $46 \mathrm{mg}, 0.4 \mathrm{mmol}$ ), and $N, N^{\prime}$ diisopropylcarbodiimide (51 $\mu \mathrm{L}, 0.4 \mathrm{mmol}$ ) and stirred at $\mathrm{rt}$ for $18 \mathrm{~h}$. The mixture was concentrated and the residue was precipitated from THF/diethyl ether twice to give a colorless solid $(855 \mathrm{mg})$. A sample $(400 \mathrm{mg})$ was taken and purified by $\mathrm{SiO}_{2}$ chromatography $\left(\mathrm{MeOH} / \mathrm{H}_{2} \mathrm{O} / \mathrm{CHCl}_{3}=1: 0: 100\right.$ to 10:0.05:100) to give crude $4(100 \mathrm{mg}$, $\sim 80 \%$ purity determined by $\left.{ }^{1} \mathrm{H}-\mathrm{NMR}\right)$ as a colorless solid. To a solution of 4 ( $80 \%$ purity) in $\mathrm{MeOH}(10 \mathrm{~mL})$ was added DIPEA $(75 \mu \mathrm{L}, 0.20 \mathrm{mmol})$ and $\mathrm{Boc}_{2} \mathrm{O}(44 \mathrm{mg}, 0.2$ $\mathrm{mmol}$ ), and the mixture was stirred at $\mathrm{rt}$ for $18 \mathrm{~h}$. The reaction mixture was concentrated and the residue was purified by precipitation (THF/diethyl ether) followed by chromatography ( $\mathrm{MeOH} / \mathrm{CHCl}_{3}, 1$ - 25\%) to give EP2-PEG1500-NHBoc (52 mg). To a solution of EP2-PEG1500-NHBoc in $\mathrm{CH}_{2} \mathrm{Cl}_{2}(2 \mathrm{~mL})$ was added TFA $(1 \mathrm{~mL})$ and the mixture was stirred for $2 \mathrm{~h}$. The reaction mixture was concentrated and the residue was re-precipitated (THF/diethyl ether) to give EP2-PEG1500- $\mathrm{NH}_{2} 4$ (42 mg). ${ }^{1} \mathrm{H}-\mathrm{NMR}$ (Brucker AMX-400, 400 MHz, CD3OD) 7.57-7.48 (6H, m), 7.33-7.29 (2H, m), 7.22$7.20(1 \mathrm{H}, \mathrm{m}), 7.10-7.09(3 \mathrm{H}, \mathrm{m}), 3.65-3.55(100 \mathrm{H}, \mathrm{m}), 2.39(2 \mathrm{H}, \mathrm{t}, J=7.6 \mathrm{~Hz}), 2.25(2 \mathrm{H}$, t, $J=7.6 \mathrm{~Hz}), 1.98-1.89(4 \mathrm{H}, \mathrm{m}), 1.73(2 \mathrm{H}, \mathrm{t}, J=6.0 \mathrm{~Hz})$. ESI-TOF MS: calcd. For $\mathrm{C}_{27} \mathrm{H}_{38} \mathrm{~N}_{3} \mathrm{O}_{4}+\left(\mathrm{C}_{2} \mathrm{H}_{4} \mathrm{O}\right)_{\mathrm{n}}:\left(\mathrm{MH}^{+}\right), 468+44 \mathrm{n}$, found 1261, 1305, 1349, 1393, 1437, 1481, 1525 (max, n=24), 1569, 1613, 1657, 1701, 1746, 1789, 1833. 
6-maleimidohexanoyl-N-PEG1500-EP2 (6). EP2-PEG1500- $\mathrm{NH}_{2} 4$ (10 mg, 5.5 $\mu \mathrm{mol}$ ) was co-evaporated twice with DMF-toluene (2:1) to remove $\mathrm{H}_{2} \mathrm{O}$, dissolved in DMF (500 $\mu \mathrm{L})$ and treated with $N$-succinimidyl-6-maleimidohexanoate 5 (3.1 mg, $10.0 \mu$ mol). After $30 \mathrm{~min}$, one crystal of DMAP $(\sim 0.1 \mathrm{mg})$ was added and the mixture was stirred at $\mathrm{rt}$ for $12 \mathrm{~h}$. The mixture was concentrated in vacuo and the residue was precipitated twice from THF/diethyl ether and titurated with hot ether to provide a colorless solid 6 (7.2 $\mathrm{mg})$ as a $\sim$ 1:1 mixture with $N$-hydroxysuccinimide (NHS). Removal of the NHS was not achieved under vacuum, chromatographic purification or recrystalization. ${ }^{1} \mathrm{H}-\mathrm{NMR}$ (Varian Gemini, $\left.400 \mathrm{MHz}, \mathrm{CD}_{3} \mathrm{OD}\right)$ 7.59-7.48 (6H, m), $7.33(2 \mathrm{H}, \mathrm{t}, J=7.6 \mathrm{~Hz}), 7.24(1 \mathrm{H}, \mathrm{m})$, 7.10-7.09 (2H, m), $6.79(2 \mathrm{H}, \mathrm{d}, J=6.0 \mathrm{~Hz}), 3.65-3.55(60-140 \mathrm{H}$, average of $100 \mathrm{H}, \mathrm{m})$, $2.81(4 \mathrm{H}, \mathrm{s}$, from NHS), $2.41(2 \mathrm{H}, \mathrm{t}, J=7.8 \mathrm{~Hz}), 2.28(2 \mathrm{H}, \mathrm{t}, J=7.8 \mathrm{~Hz}), 2.16(2 \mathrm{H}, \mathrm{t}, J=7.6$ Hz), $1.99(2 \mathrm{H}, \mathrm{t}, J=6.0 \mathrm{~Hz}), 1.97(2 \mathrm{H}, \mathrm{t}, J=7.2 \mathrm{~Hz}), 1.78-1.71(8 \mathrm{H}, \mathrm{m}), 1.62-1.54(4 \mathrm{H}, \mathrm{m})$, 1.42-1.38 (2H, m). ESI-TOF MS was accompanied by addition of $N$-hydroxysuccinimide (NHS) providing a $\mathrm{MS}$ as calcd. for $\mathrm{C}_{42} \mathrm{H}_{54} \mathrm{~N}_{4} \mathrm{O}_{10}+\left(\mathrm{C}_{2} \mathrm{H}_{4} \mathrm{O}\right)_{\mathrm{n}}$ : $\left(\mathrm{M}+\mathrm{NHS}+\mathrm{H}^{+}\right), 776+44 \mathrm{n}$, found $1437,1481,1525,1569,1613,1657,1701$. 1746, 1789 ( $\max , \mathrm{n}=24), 1833,1877$, 1922, 1965, 2010, 2054, 2098, 2141, 2185, 2229, 2273, 2318.

Stilbene-labeled CoA (1). Coenzyme A trilithium salt $(9.7 \mu \mathrm{L}$ of a $10 \mathrm{mg} / \mathrm{mL}$ aqueous stock) was added to an aliquot of 6 (3 $\mu \mathrm{L}$ of a $10 \mathrm{mM}$ stock in $100 \mu \mathrm{L}$ DMSO). The reaction was incubated at $\mathrm{rt}$ for $30 \mathrm{~min}$, at which point any remaining $\mathbf{6}$ was removed by DEAE cellulose chromatography. Fractions containing $\mathbf{1}$ and free of unreacted $\mathbf{6}$ were identified by thin layer chromatography $\left(\mathrm{CHCl}_{3} / \mathrm{MeOH} / \mathrm{AcOH} 5: 1: 0.3, R_{f} 0.70\right)$ and pooled.

\section{Production of stilbene-crypto-VibB}

A $45 \mu \mathrm{L}$ aliquot of a $250 \mu \mathrm{M}$ stock of stilbene-CoA in water was added to a solution containing $175 \mu \mathrm{M}$ MES acetate $\mathrm{pH} 6.0,25 \mu \mathrm{L}$ of purified apo-VibB ${ }^{[7]}(12 \mathrm{mg} / \mathrm{mL}$ 
stock), and $1 \mu \mathrm{L}$ of a $30 \mathrm{mg} / \mathrm{mL}$ stock of purified recombinant Sfp. This reaction was incubated at $37^{\circ} \mathrm{C}$ for $30 \mathrm{~min}$ in darkness. To confirm the presence of stilbene-cryptoVibB, the sample was then separated on a $12 \%$ Tris-Glycine polyacrylamide gel and electroblotted.

\section{Fluorescent analysis of stilbene-bound protein with anti-stilbene antibody}

A $150 \mu \mathrm{L}$ solution containing purified stilbene-crypto-VibB 1-CP $(11 \mu \mathrm{M})$ and monoclonal antibody EP2-19G2 (1.67 $\mu \mathrm{M} ; 3.33 \mu \mathrm{M}$ binding sites) in PBS (10 mM sodium phosphate, $150 \mathrm{mM} \mathrm{NaCl}, \mathrm{pH} 7.4)$ with $5 \% \mathrm{MeOH}$ co-solvent was prepared. Fluorescence intensities $\left(\lambda_{\mathrm{ex}}=327 \mathrm{~nm}, \lambda_{\mathrm{em}}=410 \mathrm{~nm}\right)$ were recorded at $23^{\circ} \mathrm{C}$ using a SpectraMax Gemini plate reader (Molecular Devices) in a 96-well black-walled plate (Costar). Measurements were performed in duplicate and all data were averaged over six scans. All data were background-corrected against buffer and $\mathrm{MeOH}$ and reported as fluorescence units (FU). Raw Results: Stilbene-bound protein + mAb EP2-19G2: 4212.9 FU. Stilbene-bound protein alone: 2301.4 FU mAb EP2-19G2 alone: 1.6 FU.

\section{Purification of crypto-VibB from crude lysate}

Stilbene-crypto-VibB 1-CP was produced in crude lysate using the procedure for production of crypto-VibB (described above), with the exception that cell lysate from $E$. coli BL21 (DE3) production strain was used as apo-VibB source. ${ }^{[7]}$ After incubation at $37^{\circ} \mathrm{C}$ for $30 \mathrm{~min}$, the reaction mixture was added to $100 \mu \mathrm{L}$ of a $1: 1$ slurry in binding buffer (50 mM Na $2 \mathrm{PO}_{4}$ [pH 8.0], $300 \mathrm{mM} \mathrm{NaCl}$ ) of Affi-gel 10 agarose beads (Biorad) conjugated to mAb EP2-19G2 according to manufacturer procedure. Binding was carried out at $\mathrm{rt}$ for $1 \mathrm{~h}$. The beads were then washed $5 \mathrm{X} 1 \mathrm{~mL}$ with binding buffer to remove any unbound proteins. Following the washes, SDS-PAGE sample buffer (100 mM Tris$\mathrm{HCl}$ [pH 6.8], 4\% SDS, $20 \%$ glycerol, $0.02 \%$ bromphenol blue) was added. The slurry was then boiled for $5 \mathrm{~min}$ and centrifuged gently to pellet the beads. To verify the 
presence of pure stilbene-crypto-VibB, the supernatant was electrophoresed using a $12 \%$ polyacrylamide gel, then electroblotted.

\section{Western blot analysis}

Following SDS-PAGE separation, the proteins in the gel were electrophoretically transferred to nitrocellulose. Blots were incubated with 5\% milk in Tris-Buffered Saline Tween-20 (TBST) at rt for 30 min with shaking. Blots were then assayed with $2 \mathrm{~mL}$ of 5\% milk in TBST solution containing $575 \mathrm{ng} / \mathrm{mL}$ mAb EP2-19G2. Following incubation at $\mathrm{rt}$ for $5 \mathrm{~h}$, the blot was washed $3 \times 5 \mathrm{~min}$ with $20 \mathrm{~mL}$ TBST. After washing, the blot was incubated with $2 \mathrm{~mL}$ of $5 \%$ milk in TBST solution containing a 1:7500 dilution of $\alpha$ murine antibody-alkaline phosphatase (Promega) for $1 \mathrm{~h}$ at $\mathrm{rt}$. The blot was then washed $3 \times 10$ min with $20 \mathrm{~mL}$ TBST before being developed with 5-bromo-4-chloro-3-indolyl phosphate/nitro blue tetrazolium (BCIP/NBT).

\section{Droplet analysis}

One $20 \mu \mathrm{L}$ droplet of nickel chromatography-purified stilbene-crypto-VibB 1-CP (11 $\mu \mathrm{M})$ in PBS was incubated with $2 \mu \mathrm{L}$ of mAb EP2-19G2 $(11.5 \mathrm{mg} / \mathrm{mL})$ on a transparent surface. Another $20 \mu \mathrm{L}$ droplet of purified 1-CP was placed on the same surface. Two $20 \mu \mathrm{L}$ droplets of BODIPY-crypto-VibB ${ }^{[7]}$ in PBS were also prepared on the surface, with one incubated with $2 \mu \mathrm{L}$ anti-BODIPY mAb $(11 \mathrm{mg} / \mathrm{mL})$ (Molecular Probes). Two additional droplets were created, one with nickel chromatography-purified purified apoVibB $(11 \mu \mathrm{M})$ and the other with nickel chromatography-purified stilbene-crypto-VibB $(11 \mu \mathrm{M}) .{ }^{[7]}$ To these were added $2 \mu \mathrm{L}$ mAb EP2-19G2 $(11.5 \mathrm{mg} / \mathrm{mL})$. All droplets were illuminated by UV light at $\lambda=302 \mathrm{~nm}$ and $\lambda=365 \mathrm{~nm}$ in order to compare the fluorescence characteristics of each reporter-antibody system. 